Publisher homepage: www.universepg.com, ISSN: 2663-7820 (Online) \& 2663-7812 (Print)

https://doi.org/10.34104/cjbis.020.24034

Canadian Journal of Business and Information Studies

Journal homepage: http://www.universepg.com/journal/cjbis

\title{
Impacts of Macroeconomic Variables on the Stock Market Returns of South Asian Region
}

\section{Quazi Nur Alam*}

Department of Business Studies, University of Information Technology and Sciences (UITS), Dhaka, Bangladesh.

*Correspondence: nur.alam@ uits.edu.bd (Quazi Nur Alam; Lecturer, Dept. of Business Studies, UITS, Dhaka, Bangladesh)

\begin{abstract}
This paper is intended to find out whether macroeconomic variables may impact on stock market as well as whether such impact has any country specific pattern. Stock market return was taken as dependent variable and real interest rate, inflation rate, GDP growth rate, foreign currency reserve growth rate, fiscal deficit, FDI to GDP ratio, exchange rate were taken as independent variables. Data-set was covered from 1993 to 2019 for five South Asian countries which were Bangladesh, India, Pakistan, Sri Lanka, and Nepal. Pattern of stock market as well as macro conditions of these countries was observed and it was found that some relationships exist between the stock market returns and these chosen independent variables. Unit root test, Heteroscedasticty test, autocorrelation test, Hausman test is conducted to authenticate and clarified data to investigate relationship nature. Granger Casualty test indicated that there exist cause and effect relationship between GDP growth rate, exchange rate, and stock market returns. Finally, regression test reveals that inflation rate and foreign currency reserve growth rate have significant impact on the stock market returns. It was expected to have unique nature of different countries having versatile impact on dependent, so additionally fixed effects model and random effects model were run and it was found that random effects model is statistically appropriate through conducting Hausman test. The test reveals that GDP growth rate, foreign currency reserve growth rate, and fiscal deficit positively impact on the stock market returns and these also support the literature review. Interest rates, inflation rate, FDI to GDP ratio and exchange rate have negatively impact the stock market return where only interest rate, inflation rate \& exchange rate.
\end{abstract}

Keywords: South Asian, Co-integration, Macroeconomic variables, Impact, Stock return, and Stock market.

\section{INTRODUCTION:}

\subsection{Preamble of the study}

A lot of interest has been generated in the field of stock market. The performance of the stock market varies due to many reasons. This paper focuses on understanding the relationship between major macroeconomic variables and the stock market returns with the passage of time. Explorative studies have been measured through gathering the required

UniversePG I www.universepg.com information. Different required variables have been taken for the analysis. The relationship between change in the performance of these stock markets and variables in the timeframe are examined.

\subsection{Objectives of this Study}

1. To determine the impact of major macroeconomic variables of 5 South Asian countries.

2. To analyze the influences of the variables on their stock market returns. 
3. To understand the determinants of stock market returns from these variables.

\subsection{Rationale of this Study}

South Asian region has made significant stride towards the development. It can be big investment fields for the foreign investors. But the performance of the stock market returns doesn't remain the same over time. Due to change in the major macroeconomic variables, the overall performance of the stock markets is influenced. This study has provided the idea about the influence of major macroeconomic variables towards the stock market of South Asian regions.

\subsection{Scope of this Study}

The study of this paper provides the understanding to learn more about the impacts of macro variables on the stock market returns of five south Asian countries for the last 25 years. It also provides the opportunity to know details about stock market condition of these five countries. Different techniques and regression analysis have been come through lessons with the literature review of impacts of macro variables on stock market returns of these countries over time.

\subsection{Limitations of the Study}

Despite the limitations of my knowledge, thinking power and skills, I tried to give best effort to understand the macro variables impacts. I had to make some assumptions because of unavailability of information. There was some confusion regarding some data and calculation process where I used my own opinions and judgments to take decision. Indices of NEPSE for 1993 \& 1994 were assumed.

\section{Literature Review}

Lots of researches have been conducted to understand the impacts of major macroeconomic variables. Sharma \& Mehendru (2010) found that inflation rate and exchange rate negatively impact the stock price index where foreign exchange reserve and gold price positively impact the market. Impacts of exchange rate and gold price were found significant. Ali (2011) conducted a research to understand the micro and macroeconomic variables on the emerging market return based on Dhaka Stock Exchange. He showed that there exists negative relationships of inflation and foreign remittance to the DSE all share price index. To realize the relationship between macroeconomic variables and the stock prices in Bangladesh, Afzal \& Hossain (2011) found that M1, M2, inflation rate have long run impact while no evidence was found regarding exchange rate on the stock price. Later

Masuduzzaman (2012) found that consumer price index, broad money supply and industrial production impact positively where exchange rate against dollar and interest rate impact negatively on the stock market index of Bangladesh. But none of these macroeconomic variables has significant impact on the stock market return. To understand the macroeconomic determinants of the performance of Indian stock market, Patel (2012) found that interest rate, gold price, silver price, oil price have negative impacts on the stock market performance. Inflation, money supply, index of industrial production has positive impact on the stock market returns. Undefined relationship of exchange rate was found on stock market index. To understand the impacts of major macroeconomic variables on stock market return. Osamwonyi \& Osagie (2012) found that interest rate, money supply (M2) have negative relationships with stock market return and inflation rate (CPI), fiscal deficit, GDP have positive relationship with stock market return. Among these macroeconomic variables, inflation rate (CPI), exchange rate, GDP and money supply have significant impact. Some variables have long run effect and some have short run effect (Gazi, 2020). By analyzing the stock market returns of Malawi, Badullahewage (2018) showed that interest rate impact negatively and exchange rate impact positively on the stock market returns.

Chet (2014) analyzed the major macroeconomic variables of Japan. They found that interest rate, inflation rate, government debt negatively impact on the stock market index while real exchange rate and index of industrial production positively impact the market. They found significant impacts of all of these variables. Salimullah (2016) analyzed the stock market of Sri Lanka and he found that GDP, balance of payments and exchange rate have positive impacts on stock market index where interest rate has negative 
impact on it. GDP, exchange rate \& interest rate have significant impact on the stock market performance (Islam and Alam, 2019).

Barakat (2015) analyzed Egypt \& Tunisia as emerging markets. They found that CPI, exchange rate and money supply positively impact on stock market index while interest rate has negative impact on stock market index. Interest rate, gold price, exchange rate and money supply all have considerable impact on stock returns in India (Nisha, 2015).

Mahzabeen (2016) found that money supply (M2) has positive relationship on stock return on DGEN while interest rate and inflation rate has negative relationship. None of these variables had significant impact. Ullah et al. (2017) showed that exchange rate, foreign currency reserve, interest rate have significant impact on stock market index while no evidence was found to understand inflation and money supply.

\section{METHODOLOGY:}

3.1 Techniques of Analysis - For analyzing and examining the impacts of macro variables on the stock market returns, regression analysis which is a great statistical tool has been used. For making the structure more specific and easier access, different independent and dependent variables have been taken.

3.2 Regression Analysis \& Model - Conditional expectation of dependable variable given independent variables is estimated through regression analysis. For finding out the regression analysis, different techniques have been developed. Linear regression and ordinary least squares regression are much familiar and parametric. Different factors of following formulas have been used. These models are used when these are less expensive in terms of money or less time consuming in terms of decision. Some examples of the usage of regression models will be presented before describing the details of modeling process. The information going to be used for making the prediction and the information going to be predicted have to be obtained from the sample of objects or the individuals. Through a linear transformation, the relationship between two parts of information is modeled.

UniversePG I www.universepg.com
3.3 Estimation - Ordinary Least Square (OLS) method is ineffective and inappropriate for the crosssectional data. Thus random effect Generalized Least Square (GLS) method has been used. According to this model, $\mathrm{Y}=\boldsymbol{\beta}_{\mathbf{0}}+\boldsymbol{\beta}_{\mathbf{1}} * \mathrm{X}_{1}+\boldsymbol{\beta}_{\mathbf{2}} * \mathrm{X}_{2}+\ldots+\boldsymbol{\beta}_{\mathbf{n}} * \mathrm{Xn}+\varepsilon$.

Where, $\mathrm{Y}$ is the dependent variable, $\boldsymbol{\beta}_{\mathbf{0}}$ is the intercept term, $\boldsymbol{\beta}_{\mathbf{n}}$ are the $\mathrm{n}$ coefficients for independent variables, $\varepsilon$ is the error term. For the impact of macro-variables analysis of five south Asian countries over the last 25 years, $Y=$ Stock Market Returns (Stock market index returns of five south Asian countries).

3.4 Sources of Data \& Information - The data and required information of the impacts of macro variables on stock market returns have been collected from different websites. Data are of last 25 years. Many websites have been browsed for gathering the information. Some data have been collected from government websites.

\subsection{Variables}

Dependent Variable: The dependent variable for the analysis is stock market return that has been calculated through the yearly indices from 1993 to 2019. For stock market returns of Bangladesh, general index of DSE from 1993 to 2012 and DSEX index from 2013 to 2019 have been used.

For India, BSE Sensex index have been used. For Pakistan, KSE100 index have been used. For Sri Lanka, all share price index of CSE has been used. Returns have been calculated by using the formula $\ln$ [(y1-yo)/yo].

Independent Variables: Real interest rate, inflation rate, GDP growth rate, foreign currency reserve growth rate, fiscal deficit, FDI to GDP ratio, exchange rate are the independent variables. Data consist of the years from 1993 to 2019.

\section{A Brief Review of South Asian Stock Markets, Challenges}

\subsection{Stock Markets}

South Asia is the southern part of Asia in the world. South Asian countries cover almost 1891 million people that make the most densely populated and 
most populous geographical region in the world. Total Nominal GDP size is \$3.12 trillion.

Dhaka Stock Exchange (Bangladesh): It is the largest strong market in Bangladesh. It was established in 1954. Total market capital is $\$ 47.20$ billion. Total market capitalization to country's GDP ratio is $27.78 \%$. DSEX index is the broad index of the market which was 5600 on $30^{\text {th }}$ August, 2018. There are 569 securities listed on it. DSEX index covers almost $97 \%$ of the total market cap. Market P/E ratio was 21.62 in 2019.

Bombay Stock Exchange (India): Almost 5.5 thousand companies are listed in it. Total size of the market cap is almost US\$2.2 trillion in April, 2018. S \& P BSE SENSEX is also called as BSE 30. BSE is the world's 10th largest stock exchange. It's the oldest stock exchange of Asia.

Karachi Stock Exchange (Pakistan): It was founded in 1947. There are almost 576 companies are listed in it. Total market capitalization covers almost $\$ 87$ billion. KSE 100 index consist of top 100 companies listed under KSE. KSE 100 index has been used for conducting the analysis in this paper. Total size of the market capitalization was $\$ 87.9$ billion.

Colombo Stock Exchange (Sri Lanka): It was established in 1985. There are 298 companies listed under CSE. Total market capitalization covers almost $\$ 18.09$ billion. Ratio of total market capital to GDP is 27.78\%. All Share Price Index is the principal stock index of CSE. Total size of the market capitalization was $\$ 48.09$ billion.

Nepal Stock Exchange (Nepal): It was established in 1993. It's the only stock exchange of Nepal. There are 70 companies are listed under NEPSE. Total market cap covers almost US $\$ 17.3$ billion. NEPSE Index is the major stock index. This index has been used for the analysis.

\subsection{Opportunities, Challenges of Stock Markets of South Asian Region}

South Asian countries have some potential of better growth aspects in the upcoming future. This region is one of the fastest growing regions in the whole world. Poverty rates are on the decrease although this region covers almost $40 \%$ of world's total poverty. Earlier UniversePG I www.universepg.com illiteracy was very strongly prevalent in this region. South Asian region is least economically integrated area in the world. Overall financial markets are getting improved. Capital inflows are received from outside parts. Greater forms of innovation in financial markets are coming. Cheaper forms of financing are proliferating of the market growths.

Transactions costs are decreasing bring to higher returns. Bilateral issues are somewhat lopsided in this region. Higher poverty dispels the aspect of development (Apriyanti, 2020). Regional policies are not strong enough to cooperate themselves. Thus it's hindering the expected regional development. Lack of information and also the interest has limited the opportunities and growths in this region. Strategic weaknesses have weakened the overall market efficiency.

There are seen lacks of interest in market developments and also the innovations. Low awareness in private sector initiatives has deteriorated the situation. Market should be more accessible for the foreign investors. Exchange control should be more efficient. Trading should be more transparent. Regional cooperation should be increased.

\section{ANALYSIS AND RESULTS:}

5.1 Descriptive Statistics - For describing the basic features of data in this analysis, descriptive statistics have been done. Total number of observations is 125 for every variable are given below (Table 1).

5.2 Unit Root Testing - When a time series faces unit root problem, the systematic pattern becomes unpredictable. Because of panel data, Levin Lin Chu unit root test method has been used to testify whether any unit root problem exist in the chosen variables. The findings from the test are given below (Table 2).

5.3 Granger Causality Test - By using empirical data sets for finding patterns of correlation, this method follows probabilistic account of the causality. For identifying the lagging, leading and the coincidence of macroeconomic variables for testing the stock market performance, Granger causality test enables to realize this. 
Table 1: Number of observations for every variable.

\begin{tabular}{|l|c|c|c|c|}
\hline \multicolumn{1}{|c|}{ Variable } & Mean & Std. Dev & Minimum & Maximum \\
\hline Market Return & $10.55 \%$ & $29.30 \%$ & $-74.33 \%$ & $81.20 \%$ \\
\hline Real Interest Rate & $4.38 \%$ & $4.12 \%$ & $-10.25 \%$ & $14.82 \%$ \\
\hline Inflation Rate & $7.50 \%$ & $3.58 \%$ & $2.00 \%$ & $22.56 \%$ \\
\hline GDP Growth Rate & $4.75 \%$ & $2.25 \%$ & $-2.22 \%$ & $10.25 \%$ \\
\hline For. Cur. Res. Growth Rate & $17.58 \%$ & $38.0 \%$ & $-68.86 \%$ & $156.75 \%$ \\
\hline Fiscal Deficit & $4.97 \%$ & $1.74 \%$ & $0.70 \%$ & $9.85 \%$ \\
\hline FDI to GDP Ratio & $0.96 \%$ & $0.75 \%$ & $-0.10 \%$ & $3.67 \%$ \\
\hline Exchange Rate & 0.01653 & $0.62 \%$ & -0.0066 & 0.0356 \\
\hline
\end{tabular}

Table 2: Findings of Unit Root Testing.

\begin{tabular}{|c|c|c|}
\hline Variables & Adjusted t & p Value \\
\hline Interest Rate & -3.23 & 0.0006 \\
\hline Inflation Rate & -3.85 & 0.0001 \\
\hline GDP Growth Rate & -4.16 & 0.0000 \\
\hline For. Cur. Res. & -7.31 & 0.0000 \\
Growth Rate & & \\
\hline Fiscal Deficit & -2.41 & 0.0080 \\
\hline FDI to GDP & -2.92 & 0.0017 \\
\hline Exchange Rate & -5.60 & 0.0000 \\
\hline
\end{tabular}

From the result it can be conclude that there exists no unit root problem in the model.
By conducting Granger causality test in views, it's found that GDP growth rate and exchange rate have rejected the null hypotheses at $10 \%$ level of significance. It indicates that there exists cause and effect relationship between GDP growth rate and exchange rate.

GDP growth rate and exchange rate have a predictive relationship at $10 \%$ level of significance. The overall Granger causality tests indicates no significant relationship between stock market returns and the rest macroeconomic variables in strongly indicates the evidence of the informational inefficiency in the market.

\subsection{Correlation Matrix \& VIF Test}

\begin{tabular}{|l|c|c|c|c|c|c|c|c|}
\hline \multicolumn{1}{|c|}{ Variables } & $\mathbf{1}$ & $\mathbf{2}$ & $\mathbf{3}$ & $\mathbf{4}$ & $\mathbf{5}$ & $\mathbf{6}$ & $\mathbf{7}$ & $\mathbf{8}$ \\
\hline Real Interest Rate (1) & 1.00 & & & & & & & \\
\hline Inflation Rate (2) & 0.39 & 1.00 & & & & & & \\
\hline GDP Growth Rate (3) & -0.03 & 0.18 & 1.00 & & & & & \\
\hline For. Cur. Res. Growth Rate (4) & 0.06 & 0.15 & 0.10 & 1.00 & & & & \\
\hline Fiscal Deficit (5) & -0.20 & -0.28 & 0.13 & -0.07 & 1.00 & & & \\
\hline FDI to GDP (6) & 0.06 & -0.34 & -0.42 & -0.03 & -0.10 & 1.00 & & \\
\hline Exchange Rate (7) & -0.37 & -0.28 & -0.20 & -0.17 & 0.14 & 0.18 & 1.00 & \\
\hline Cons & -0.07 & -0.27 & -0.42 & -0.08 & -0.55 & 0.05 & -0.40 & 1.00 \\
\hline
\end{tabular}

When the correlation is 1.00 , it indicates two variables are perfectly correlated. All these independent variables are moderately correlated with one another. Variance Inflation Factor (VIF) indicates the ratio of the variance in any model with the multiple terms divided by variance of a model with one term alone. The Variance Inflation factor (VIF) 
test in Stata software shows that the mean is 1.29. It assures that there is no multicollinearity problem.

5.5 Johansen Co-integration - The outcome through conducting the test shows the existence of 1 cointegrating equation at $5 \%$ level of significance. One linear combination exists between variables that force the indices to remain a relationship over the time period I meant by that co-integration equation. The Maximum Eigen value test shows one co-integrating equations at $5 \%$ level of significance confirming trace test. From the result, it can be realized that there exists co-integration at most 1,2,3,4,5 CEs both from trace test and max-eigen test.

5.6 Heteroscedasticity Test - By conducting Heteroscedasticity test in Stata software, $p$ value was found as 0.8006. Null hypothesis was constant variance. High $\mathrm{p}$ value indicates that Heteroscedasticity isn't a problem here.

\subsection{Autocorrelation or Serial Correlation -} Through conducting Breusch Godfrey test for autocorrelation in Stata, $\mathrm{p}$ value was found as 0.5662 that clearly tells no serial correlation is exist in the model.

\subsection{Regular Multiple Regression, Fixed Effects} Model, Randome Effects Model - The R squared value becomes 0.0947 . The adjusted $\mathrm{R}$ squared becomes 0.0405 and the root MSE becomes 0.29292. Total number of observations was 125 . It indicates that among all the independent variables, the impact of foreign currency growth rate becomes significant at $5 \%$ level of significant. And the impact of inflation rate becomes significant at $10 \%$ level of significance. It's found that, some countries have the highly different values while in some area countries are best for their different other variables.

In fixed effects model, Here $\mathrm{R}$ square is within 0.0996 , between 0.5081 , overall 0.0903 . $F(7,113)=$ 1.79. Prob $>F=0.096$. Corr $=-0.1603$. It means all the independent varaibles can impact by $9.96 \%$ on the stock market return. $\mathrm{P}$ value 0.09 indicates the model is not weak. Random effects model follow GLS regression equation. Generalized Least Square regression method is being followed by random effect model because of cross sectional data.

Here, R square is within 0.0975, between 0.5465, overall 0.0947 . Wald chi2 $(7)=12.23$. Prob $>$ chi $2=$ 0.0932. Corr $=0$. It means all the independent varaibles can impact by $9.75 \%$ on the stock market returns. $\mathrm{P}$ valoe 0.09 indicates the model is not weak. The comparison among the multiple regression model, fixed effects model and random effects model is given below (Table 3).

From the comparison, we can understand that random effects model and multiple linear regressions provide almost the same result. The coefficients of the independent variables under these two methods become almost same. The $\mathrm{p}$ values under these models become similar too.

Table 3: Coefficients of independent variables under multiple regression, fixed effects and random effects model.

\begin{tabular}{|l|c|c|c|c|c|c|}
\hline \multicolumn{1}{|c|}{ Regression Model } & \multicolumn{2}{c|}{ Multiple Regression } & \multicolumn{2}{c|}{ Fixed Effect } & \multicolumn{2}{c|}{ Random Effect } \\
\hline Variables & Coef. & P >ItI & Coef. & P $>$ ItI & Coef. & P > IzI \\
\hline Interest Rate & -0.778 & 0.294 & -0.917 & 0.269 & -0.778 & 0.292 \\
\hline Inflation Rate & -1.379 & 0.1 & -1.352 & 0.1 & -1.379 & 0.1 \\
\hline GDP Growth Rate & 1.724 & 0.194 & 1.622 & 0.317 & 1.734 & 0.192 \\
\hline For. Cur. Res. Growth Rate & 0.165 & 0.022 & 0.153 & 0.038 & 0.165 & 0.021 \\
\hline Fiscal Deficit & 1.033 & 0.531 & 0.7 & 0.753 & 1.033 & 0.529 \\
\hline FDI to GDP & -2.622 & 0.523 & -4.596 & 0.348 & -2.622 & 0.522 \\
\hline Exchange Rate & -3.079 & 0.519 & -4.259 & 0.471 & -3.079 & 0.518 \\
\hline Cons & 0.156 & 0.224 & 0.223 & 0.225 & 0.156 & 0.221 \\
\hline
\end{tabular}


5.9 Hausman Test - Through conducting the Hausman test, we can understand between fixed effect and random effect model, which option provides the best result to our model. Here is the outcome of Hausman test (Table 4).

Table 4: Outcome of the Hausman test.

\begin{tabular}{|l|c|c|c|c|}
\hline Variables & Fixed & Random & Difference & SQRT S.E. \\
\hline Interest Rate & -0.917 & -0.778 & -0.139 & 0.369 \\
\hline Inflation Rate & -1.352 & -1.379 & 0.026 & 0.215 \\
\hline GDP Growth Rate & 1.622 & 1.734 & -0.112 & 0.918 \\
\hline For. Cur. Res. Growth Rate & 0.153 & 0.165 & -0.012 & 0.016 \\
\hline Fiscal Deficit & 0.700 & 1.033 & -0.332 & 1.494 \\
\hline FDI to GDP & -4.596 & -2.622 & -1.974 & 2.656 \\
\hline Exchange Rate & -4.259 & -3.079 & -1.180 & 3.472 \\
\hline
\end{tabular}

Two tailed $\mathrm{p}$ values indicate that only foreign currency reserve growth rate has significant influence on the market return. And inflation rate is significant at $10 \%$ level of significance. From them, some which have negative impact of the stock market performance over the last years. Different factors were the most dominant performance indicator in that time period. The result and the impacts of variables on market return are given as below:

5.10 Regression Equation - Through conducting the test the regression equation becomes;

$$
\begin{aligned}
& \mathrm{SMR}=0.1563-0.7779 * \mathrm{INR}-1.3787 * \mathrm{INF}+1.7341 * \\
& \mathrm{GGR}+0.1646 * \mathrm{FCRGR}+1.0327 * \mathrm{FD}-2.6216^{*} \\
& \text { FDIGDP-3.0788 } * \mathrm{ER}
\end{aligned}
$$

Where, SMR = Stock Market Returns, INR= Interest Rate, INF= Inflation Rate, GGR= GDP Growth Rate, FCRGR $=$ Foreign Currency Reserve Growth Rate, $\mathrm{FB}=$ Fiscal Deficit, FDIGDP= FDI to GDP Ratio, ER= Exchange Rate.

\subsection{Impacts of Different Variables on Market Return}

Real Interest Rate: The coefficient of real interest rate is -0.7779 . It indicates that there exists negative relationship between the stock market return and the real interest rate. Due to $1 \%$ increase in real interest rate, it leads to $0.77 \%$ decrease on the stock market
Hausman fixed random reveals that difference in coefficient is not systematic (Prob $>$ chi $2=0.9949$ ). If $\mathrm{p}$ $>0.05$, random effect outcome is best suitable for the test. Thus random effect can be used for analysis. Wald chi2 $(6)=12.23$ indicates the perfection model that is used on the market return. return. P value 0.292 which is higher than 0.05 that indicates the impact isn't significant.

Inflation Rate: The coefficient of real inflation is 1.3787. It indicates that there exists negative relationship between the stock market return and the inflation rate. Due to $1 \%$ increase in inflation rate, it leads to $1.38 \%$ decrease on the stock market return. $\mathrm{P}$ value 0.124 which is higher than 0.05 that indicates the impact isn't significant. But at $10 \%$ level of significance, we may consider it as significant.

GDP Growth Rate: The coefficient of GDP growth rate is 1.7341. It indicates that there exists positive relationship between the stock market return and the GDP growth rate. Due to $1 \%$ increase in GDP growth rate, it leads to $1.73 \%$ increase on the stock market return. $\mathrm{P}$ value 0.192 which is higher than 0.05 that indicates the impact isn't significant.

Foreign Currency Reserve Growth Rate: The coefficient of foreign currency reserve growth rate is 0.1646. It indicates that there exists positive relationship between the stock market return and the foreign currency reserve growth rate. Due to $1 \%$ increase in foreign currency reserve growth rate, it leads to $0.1646 \%$ increase on the stock market return. $\mathrm{P}$ value 0.021 which is lower than 0.05 that indicates the impact is significant. 
Fiscal Deficit: The coefficient of real interest rate is 1.0327. It indicates that there exists positive relationship between the stock market return and the fiscal deficit. Due to $1 \%$ increase in fiscal deficit, it leads to $1.0327 \%$ increase on the stock market return. $\mathrm{P}$ value 0.529 which is higher than 0.05 that indicates the impact isn't significant.

FDI to GDP Ratio: The coefficient of real interest rate is -2.6216 . It indicates that there exists negative relationship between the stock market return and the FDI to GDP ratio. Due to $1 \%$ increase in FDI to GDP ratio, it leads to $2.6216 \%$ decrease on the stock market return. $\mathrm{P}$ value 0.522 which is higher than 0.05 that indicates the impact isn't significant.

Exchange Rate: The coefficient of exchange rate is 3.0788. It indicates that there exists negative relationship between the stock market return and the exchange rate. Due to $1 \%$ increase in exchange rate, it leads to $3.0788 \%$ decrease on the stock market return. $\mathrm{P}$ value 0.518 which is higher than 0.05 that indicates the impact isn't significant.

For collecting the coefficient, probability factor is used for the regression analysis tools and software. From the analysis, it's found that some independent variables have positive impact on the market return and the degree of influences is significant. In comparison with that, some independent variables have negative effect on market return and the degree of influence is insignificant. The countries are much competitive in market but their performance is somewhat not equal to other markets in many other countries. A little bit significant impact is noticed on stock market returns for different variables.

\subsection{FINDINGS OF THE STUDY:}

The purpose of the paper was to analyze the impacts of macroeconomic variables on the stock market returns of selected South Asian countries. All the information is gathered from different sources. All data are categorized with different variables. The literature review provides the understanding of the impacts of major macroeconomic variables on the stock market returns based on previous researches. The first objective of the paper was to determine the impact of major macroeconomic variables of the chosen countries on the stock market returns. It's found that inflation rate and foreign currency reserve growth rate have significant impacts on the stock market returns. Second objective was to analyze the influences of the chosen independent variables on the stock market returns. By conducting unit root testing in Stata, no problem was found with the chosen independent variables.

Levin Lin Chu unit root test was applied in it. All the variables were found as stationary. For understanding whether the time series is useful enough for forecasting about the future and to understand the cause-effect relationship, Granger Causality test was conducted. It's found that there exists cause-effect relationship GDP growth rate and exchange rate on stock market returns. It also indicated that no significant relationship was found to predict with the evidence of informational inefficiency. Conintegration outcome from Maximum Eigen value test shows there exist conintegration relationship. For more accuracy of the analysis, different other tests had been conducted. By conducting serial correlation test, heteroscedasticty test, multicollinearity test thorough variance inflation factor no problem was seen.

Because of choosing different countries through considering unique nature having versatile impact on stock market returns, fixed effects and random effects model were run too. It's found that random effects model is appropriate for the test according to the hausman test outcome. It's found that there exists positive relationship between stock market returns and GDP growth rate, foreign currency reserve growth rate, fiscal deficit. And there exists negative relationship between interest rate, inflation rate, FDI to GDP ratio, exchange rate. Inflation rate and foreign currency reserve growth rate have significant impact on the stock market returns of South Asian countries.

Third objective of the paper was to identify the major determinants of stock market returns. It's found that exchange rate has the most influence among all the independent variables on the stock market returns due a small change in it. As inflation rate and foreign currency reserve growth rate impact significantly on the stock market returns, these are strong determinants of the stock market performance. 


\section{CONCLUSION AND POLICY IMPLICATIONS:}

The objective of the paper was to find out the impact of different macroeconomic variables on the stock market returns of five south Asian countries. This paper found that there exist positive and negative relationship with these variables and stock market returns. Real interest rate, inflation, FDI to GDP ratio and exchange rate negatively impact on the stock market return where GDP growth rate, foreign currency reserve growth rate, fiscal deficit positively impact on the stock market return. The impact of foreign currency growth rate is significant on the stock market returns. The impact of inflation is also significant at $10 \%$ level of significance. Findings from the study have some crucial policy implications. Foreign currency reserve growth rate contains significant information for forecasting the stock market returns of south Asian countries. So that the central banks of these five south Asian countries should try to ensure higher growth is foreign currency reserve growth rate. Inflation rate has too significant impact on stock market returns. Policy makers should try to limit the inflation rate at a certain level. The Granger causality test result implies that the stock market returns from five south Asian countries can't be predicted by using these macro-variables except foreign currency reserve growth rate and inflation.

\section{ACKNOWLEDGEENT:}

All praise belongs to the Almighty Allah. Author would like to express his gratitude to all the people who were involved both directly and indirectly in the preparation of this paper. Author conveys his overall gratitude to the persons who have been involved in assisting him to provide the data, give guidelines in many aspects.

\section{COFLICTS OF INTEREST:}

The author declares that there is no conflict of interest in this paper.

\section{REFERECES}

1. Afzal N., and Hossain SS. (2011). An Empirical Analysis of the Relationship between Macroeconomic Variables and Stock Prices in Bangladesh, Bangladesh Development Studies, 34(4), 95-105

UniversePG I www.universepg.com
2. Ali, M. (2011). Impact of Micro and Macroeconomic Variables on Emerging Stock Market return: A Case on Dhaka Stock Exchange (DSE). Interdisciplinary Journal of Research in Business, 1(5), 08-16.

3. Apriyanti HW. (2020). Measurement and assessment of the developmental status of Islamic University governance: Indonesia perspective, Int. J. Manag. Account. 2(1), 1021. https://doi.org/10.34104/ijma.020.10021

4. Badullahewage SU. (2018). The effects of macroeconomic factors on the performance of stock market in Sri Lanka, Inter. J. of Innovation and Econo. Develop., 3(6): 33-41. http://dx.doi.org/10.18775/ijied.1849-75517020.2015.36.2002

5. Barakat, M., Elgazzar, S. and Hanafy, K. (2015). Impact of Macroeconomic Variables on Stock Markets: Evidence from Emerging Markets. International Journal of Economics and Finance, 8(1), 195.

https://doi.org/10.5539/ijef.v8n1p195

6. Chet, Z. (2014). The impact of Macroeconomic Variables on the Stock Market Performance in Japan.

http://eprints.utar.edu.my/1263/1/FN-20141102348.pdf

7. Gazi MAI. (2020). E-marketing practice in Bangladesh: an empirical study on trend of use and expansion in business, Can. J. Bus. Inf. Stud., 2(1), 12-23. https://doi.org/10.34104/cjbis.020.012023

8. Islam MT, and Alam MJ. (2019). The relationship between informal economy and GDP growth: a study on south-asian developping countries. Can. J. Bus. Inf. Stud., 1(5), 01-09.

https://doi.org/10.34104/cjbis.019.0109

9. Mahzabeen, S. (2019). Impact of Money, Interest Rate and Inflation on Dhaka Stock Exchange (DSE) of Bangladesh. Journal of Business and Technology (Dhaka), 11(1), 41. https://doi.org/10.3329/jbt.v11i1.34241

10. Masuduzzaman, M. (2012). Impact of the Macroeconomic Variables on the. Stock Market Returns: the stock market index of 
Bangladesh. Global Journal of Management And Business Research,

https://journalofbusiness.org/index.php/GJMB R/article/download/

11. Nisha, N. (2015). Impact of Macroeconomic Variables on Stock Returns: Evidence from Bombay Stock Exchange (BSE). Journal of Investment and Management, 4(5), 162. https://doi.org/10.11648/j.jim.20150405.14

12. Osamwonyi, I. and Evbayiro-Osagie, E. (2012). The Relationship between Macroeconomic Variables and Stock Market Index in Nigeria. Journal of Economics, 3(1), 55-63. https://doi.org/10.1080/09765239.2012.11884 $\underline{953}$

13. Patel, S. (2012). The effect of Macroeconomic Determinants on the Performance of the Indian Stock Market. NMIMS Management Review, 22:117-127.
14. Salimullah AHM. (2016). Granger Causality of Interest Rate and Exchange Rate on Stock Volatility at Chicago Options Market, Scientia et Humanitas: A Journal of Student Research, 35-54.

15. Sharma, GD. and Mahendru, M. (2010). Impact of Macroeconomic Variables on Stock Prices in India. Global J. of Management and Business Res., 10(7): 1-18. https://papers.ssrn.com/sol3/papers.cfm?abstra ct_id=1827462

16. Ullah, GMW., Islam, A., Alam, M., and Khan, M. (2019). Effect of Macroeconomic Variables on Stock Market Performance of SAARC Countries. Asian Economic and Financial Review, 7(8), 770-779.

http://dx.doi.org/10.18488/journal.aefr.2017.7 $\underline{8.770 .779}$

\section{APPENDICS}

\begin{tabular}{|l|c|l|c|c|}
\hline \multicolumn{5}{|c|}{ ADF } \\
\hline Residual variance & 0.141819 & & t-Statistic & Prob. \\
\hline HAC variance & 0.027479 & & -2.912799 & 0.0018 \\
\hline Variable & Coefficient & Std. Error & t-Statistic & Prob. \\
\hline RESID (-1) & -1.179696 & 0.124505 & -9.475105 & 0 \\
\hline D (RESID(-1)) & 0.22836 & 0.088718 & 2.574012 & 0.0113 \\
\hline R-squared & 0.514887 & Mean dependent var & & -0.0005 \\
\hline Adjusted R-squared & 0.510594 & S.D. dependent var & & 0.39468 \\
\hline S.E. of regression & 0.276105 & Akaike info criterion & & 0.28117 \\
\hline Sum squared resid & 8.614451 & Schwarz criterion & & 0.32891 \\
\hline Log likelihood & -14.1672 & Hannan-Quinn criter. & & 0.30055 \\
\hline Durbin-Watson stat & 2.074658 & & & \\
\hline
\end{tabular}

\begin{tabular}{|l|c|c|}
\hline Null Hypothesis: & F-Statistic & Prob. \\
\hline D (INDEX_RETURN) does not Granger Cause D (INT_RATE) & 1.87462 & 0.1585 \\
\hline D (INT_RATE) does not Granger Cause D (INDEX_RETURN) & 0.31485 & 0.7306 \\
\hline D (INDEX_RETURN) does not Granger Cause D (INFLA) & 1.62402 & - \\
\hline D (INFLA) does not Granger Cause D (INDEX_RETURN) & 0.16015 & - \\
\hline D (GDP_GRO) does not Granger Cause D (INDEX_RETURN) & 2.63658 & 0.0763 \\
\hline D (INDEX_RETURN) does not Granger Cause D (GDP_GRO) & 3.944 & 0.0223 \\
\hline D (INDEX_RETURN) does not Granger Cause D (FXCRESGR_RATE) & 2.29482 & - \\
\hline D (FXCRESGR_RATE) does not Granger Cause D (INDEX_RETURN) & 0.71455 & - \\
\hline
\end{tabular}




\begin{tabular}{|l|l|l|}
\hline D (INDEX_RETURN) does not Granger Cause D (FIS_DEF) & 5.74522 & 0.0043 \\
\hline D (FIS_DEF) does not Granger Cause D (INDEX_RETURN) & 0.72508 & 0.4867 \\
\hline D (INDEX_RETURN) does not Granger Cause D (FDI_GDP) & 0.36264 & 0.6967 \\
\hline D (FDI_GDP) does not Granger Cause D (INDEX_RETURN) & 0.94079 & 0.3936 \\
\hline D (INDEX_RETURN) does not Granger Cause D (EXRATE) & 5.14552 & 0.0074 \\
\hline D (EXRATE) does not Granger Cause D (INDEX_RETURN) & 2.10646 & 0.1268 \\
\hline
\end{tabular}

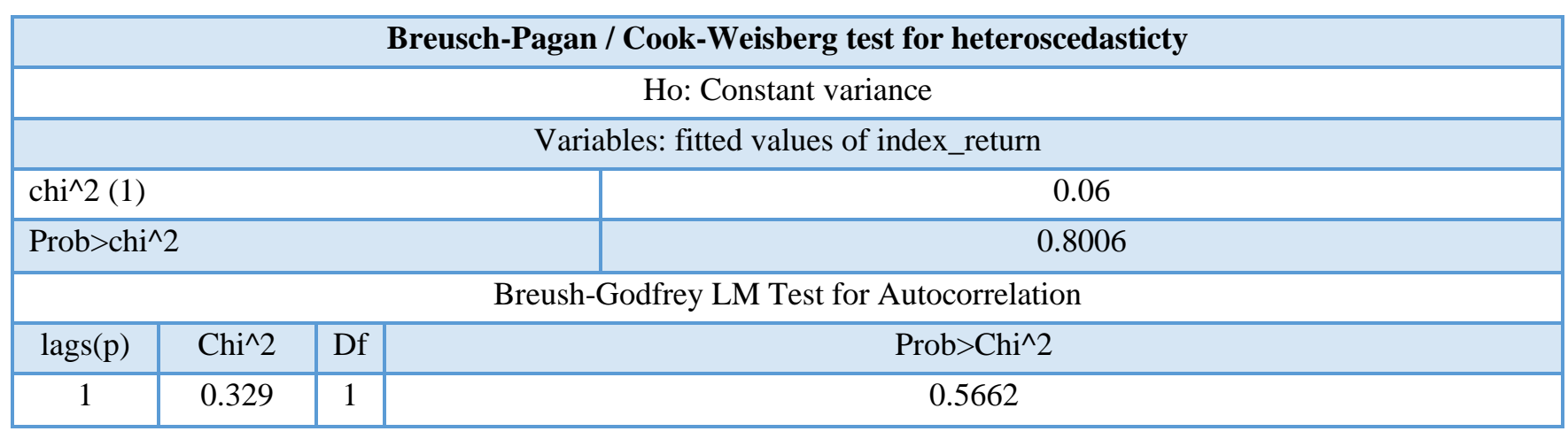

\begin{tabular}{|l|c|c|}
\hline \multicolumn{1}{|c|}{ Variable } & VIF & 1/VIF \\
\hline Inflation & 1.49 & 0.67 \\
\hline FDI to GDP & 1.38 & 0.72 \\
\hline Interest rate & 1.34 & 0.75 \\
\hline GDP Growth Rate & 1.3 & 0.77 \\
\hline Exchange Rate & 1.28 & 0.78 \\
\hline Fiscal Deficit & 1.17 & 0.85 \\
\hline For. Cur. Res. Growth Rate & 1.05 & 0.95 \\
\hline Mean VIF & 1.29 & \\
\hline
\end{tabular}

Citation: Alam QN. (2020). Impacts of macroeconomic variables on the stock market returns of South Asian region, Can. J. Bus. Inf. Stud., 2(2), 24-34. https://doi.org/10.34104/cjbis.020.24034 @) क 